\title{
Mediating Effect of Capital Expenditure on the Effect of Revenues, Allocation Fund, and Tax/Nontax Sharing on Economic Growth (Empirical Study of Regencies in Bengkulu Province Period of 2009-2015)
}

\author{
Elsivera $^{1^{*}}$ and Willy Abdillah ${ }^{2}$ \\ ${ }^{1}$ University of Bengkulu, Bengkulu, Indonesia
}

\begin{abstract}
This research examines the mediating effect of capital expenditure on the relationship between regional revenues (PAD), general allocation fund (DAU), specific allocation fund (DAK), and tax sharing fund/non tax sharing $(D B H)$ on the economic growth. Secondary data were collected from 10 regencies in Bengkulu Province for the period of 2009 to 2015. This research used panel data analysis. The results showed that capital expenditure did not mediate the relationship between regional generated revenues, general allocation fund, specific allocation fund, and tax sharing fund/non tax sharing to economic growth. Meanwhile, general allocation fund have positif effect on economic growth. Regional generated revenues and specific allocation fund have negative effect on economic growth, regional revenues and specific allocation fund also have positive effect on capital expenditure. Implication for stakeholders and further research are discussed.
\end{abstract}

Keywords: Capital Expenditure, Economic Growth, General Allocation Fund, Regional Generated Revenues, , Specific Allocation Fund, Tax Sharing Fund /Non Tax Sharing

\section{INTRODUCTION}

Reform of local financial management in Indonesia in the form of fiscal decentralization, aims to encourage the realization of good governance. It is governed by Law Number 2 Year 2015 and Law Number 33 Year 2004, which explains the objectives of fiscal decentralization within the framework of the implementation of regional financial management in Indonesia is for fiscal sustainability, corrects vertical imbalance, corrects horizontal imbalance, reduces dependency regional levels to the center, increasing accountability, effectiveness and efficiency in the framework of improving regional performance, improving the quality of public services, and increasing public participation in decision making in the public sector. Thus, fiscal decentralization is a central government financial management instrument in distributing resources in the form of budgets to regions to realize public services which in turn leads to prosperity. The budget distribution process from the central government to local governments is manifested in the form of balancing fund transfer (Saragih 2003: 83).

According to Law No. 2 of 2015 article 288 and Act No. 33 of 2004 Article 10 , the balance fund consists of tax-sharing / non-tax revenue-sharing funds, DAU,

* Corresponding author. Email address: ciciferry76@gmail.com 
and DAK. Balancing Funds are also called transfers or grants. In line with the objective of fiscal decentralization, transfers aim to reduce horizontal financial inequality between regions, reduce central and regional vertical gaps, address the effects of public service delivery among regions, and create stability of economic activity in the regions.

Decades of decentralization have been passed, but in reality the regions are still heavily dependent on balancing transfers, thus still the main source of revenue for local government Expenditure. This is indicated in 2013, the share of district / city equity funds in Indonesia is 72.61 percent ( $\mathrm{Rp} 378.26$ billion) of the total revenue of districts / cities in Indonesia. This reality shows that the average districts / cities in Indonesia are still not able to independently by increasing the taxing power of regions through local revenue (PAD) as the main support of local Expenditure. This is due to many inefficient enterprises, local levies have begun to be trimmed due to causing high cost economy and hampering investment.

However, with the implementation of fiscal decentralization through the pattern of balancing funds is expected to create an increase in regional economic activity that in real terms have an impact on increasing regional independence through increasing PAD. Excavation of local tax potency, regional retribution, result of separated regional wealth management and other legitimate PAD for the improvement of PAD should duly improve the regional capability in allocating capital expenditure for infrastructure development well.

Furthermore, if local governments want to achieve economic growth objectives, then the implication of the government should be to set the appropriate direction of public finance policy and public financial management. Mahmudi (2010: 14) states that the key to the success of local financial management is actually located manajamen income, expenditure management and financing management. This means that the success of APBD management depends heavily on the pattern of allocating resources through revenue management, the pattern of Expenditure arrangements through expenditure management and coping patterns of deficit and surplus through financing management by local government. Accuracy in financial management is a driving force of economic activity of the society.

Meanwhile, Article 66 of Law Number 33 Year 2004 mandates that regional finance should be managed in an orderly, law-abiding, efficient, economical, effective, transparent and accountable manner with due regard to justice, compliance and benefits to the community. The law provides a framework to local governments in managing local finances to provide the greatest benefit to the community. That is, the allocation of development Expenditure that will increase capital investment in the form of fixed assets ie equipment, buildings, infrastructure and other fixed assets by the local government is absolutely done. The higher level of capital investment is expected to improve the quality of public services. The allocation of capital expenditure is based on the regional need for facilities and infrastructure, both for the smooth implementation of government duties and for public facilities. Improving public services is expected to encourage a better investment climate in the region so it can be an attraction for investors to open businesses in the region.

The role of capital Expenditure in promoting growth has been assessed in earlier empirical studies. Kuspita (2015) found that capital expenditures mediated the effects of PAD, DAU, SiLPA on regional economic growth the following year. 
Mediating Effect of Capital Expenditure on the Effect of Revenues, Allocation Fund, and Tax/Nontax Sharing on Economic Growth (Empirical Study of Regencies in Bengkulu Province

In line with that, Muis (2012) reported that capital expenditures can mediate the relationship between DAU and DAK with economic growth. However, Uhise (2013) finds capital Expenditure mediating negatively the relationship between DAU and DAK with economic growth. In fact, Afriani et al. (2012) did not find any effect of capital expenditure mediation on the relationship between PAD and DAU with economic growth. The inconsistency of the findings of these studies, giving researchers the opportunity to review the role of capital expenditure mediation.

This paper describes the results of studies on the effect of capital expenditure mediation on the effect of PAD, DAU, DAK, DBH on economic growth. Systematic exposure begins from literature review, research methods, and discussion of research findings. The final section of this paper discusses the implications of research findings for similar studies and stakeholders.

\section{LITERATURE BACKGROUND}

\section{Agency Theory}

According to Jensen and Meckling (1976), agency relationships are defined as contractual relationships between principals and agents enabling principals as the owner of the capital to delegate authority to the agent for its importance. The consequence that must be borne by the agent as the recipient of the delegation of authority is to account the performance to the principal as the owner of capital. Furthermore, if there is an equally strong economic boost from both parties in the relationship, then it is possible that the agent can not always make decisions in accordance with the wishes of the owner of capital. Conflicts of interest is then called the term agency conflict. The clash raises moral hazard and adverse selection, ie the agent does not run the deal.

In the context of government organizations, the people as principals mandate the government as an agent, to organize the government in order to improve the welfare of the community. But in the process of carrying out these mandates, there is often an asymmetric desire or purpose between the principal and the agent, especially on public sector budgeting. This is because of the tendency of the agent to be opportunistic in allocating the budget so that it is not in accordance with the wishes and goals of the capital owner in delegating his authority.

Implementation of principal agent theory in Indonesia, especially in the process of budget preparation is on budget allocation process which is result of cooperation of two parties, which is legislative and executive. The form of agency responsibility is to realize the welfare of society in regencies / city in Bengkulu Province. In addition, the community as a principal must know the budget management information conducted by the agent, so that no information asymmetry occurs.

One indicator of the welfare of the community is economic growth. Economic growth also signifies the successful development of a region. If economic growth increases then the level of people's welfare and productivity will be higher, so unemployment is reduced and poverty goes down. Economic growth can be achieved when APBD expenditure is allocated efficiently and effectively, meaning that budgeting focuses on programs that are capable of driving the wheels of the community's economy. If a program is efficient and effective in realizing the 
fulfillment of public needs, then the program is said to be effective in the realization of expenditure.

\section{Hypotheses \\ Capital Expenditure mediates PAD Effect on Economic Growth}

PAD is one of the indicators of regional autonomy because the increase in PAD reduces the regional fiscal dependence on the central government so that regions become autonomous. Increased PAD can encourage local government capital expenditures, such as facilities and infrastructure, infrastructure in the form of land, equipment and machinery, buildings and buildings, roads, networks and irrigation and other fixed assets, which in turn is expected to encourage increased regional economic growth through improved investment climate area.

Previous empirical studies have found a positive influence of PAD on economic growth (Andriana, 2009) through the improvement of public service facilities (Gunantara and Dwirandra, 2014). Increased PAD provides local flexibility in developing its economic agenda (Brata, 2004) as long as the regions are not too offensive in an effort to increase local revenue.

Meanwhile, other study groups found positive influence of PAD on capital expenditure (Kusnandar and Siswantoro, 2012; Solikin, 2007). PAD encourages LGs to realize capital expenditures for the next year. Increased capital investment is expected to improve the quality of public services (Mardiasmo, 2002). Thus, PAD becomes one of the decisive factors in determining the allocation of capital expenditure. The larger the PAD received will increase the allocation of regional capital expenditures that ultimately drive economic growth. Therefore, the proposed hypothesis is as follows.

H1: Capital Expenditure mediates PAD effect on economic growth

\section{Capital Expenditure mediates DAU Effect on Economic Growth}

DAU is one of the regional financing sources derived from central government balancing fund which is a block grant. The allocated DAU aims to reduce the inequality of financial capacity between central and local governments as well as between local governments. Local governments are given full authority in the management of DAU, but must be adjusted to the priorities and needs of the regions for improving services to the community within the framework of decentralization.

DAU can be allocated to direct expenditure, such as capital expenditures and indirect Expenditure, ie personnel expenditure. The direct expenditure is intended for the administration of obligatory affairs as well as the affairs of choice. Expenditure on business should be prioritized in order to realize the regional government's sustainability and investment in the form of improving basic services, education, health, social facilities and decent public facilities and developing social security system (Permendagri No. 52 year 2015). With the increase of DAU in the form of capital expenditure, it can encourage economic growth (Sumartini, 2015, Kuspita, 2015, Oktriniatmaja, 2011; Anriati, 2010; Hendriwiyanto, 2014) and PDRB (Kurni, 2012), especially when DAU as a source of financing both development of facilities and infrastructure infrastructure that will impact on regional economic growth. Thus, the proposed hypothesis is as follows. 
Mediating Effect of Capital Expenditure on the Effect of Revenues, Allocation Fund, and Tax/Nontax Sharing on Economic Growth (Empirical Study of Regencies in Bengkulu Province

H2: Capital Expenditure mediates DAU effect on economic growth

\section{Capital Expenditure mediates DAK Effect on Economic Growth}

DAK transfers by the government for specific regions aim at reducing local burdens in funding special activities that are regional affairs and in line with national priorities. DAK is a Special Grant, meaning that its designation has been determined by the central government. DAK is allocated to realize the balance of prioritized inter-regional public services in the areas of education, health, infrastructure, marine, fisheries, livestock, local government infrastructure and the environment. Effective and effective DAK management of the procurement, development, upgrading and rehabilitation of the infrastructure is expected to increase the economic life of public service infrastructure in developing the local economy (Taaha et al., 2009; Santosa, 2013). Thus, the utilization of DAK should be directed to the capital expenditures of Novianto and Hanafiah, 2015). Increased capital expenditure sourced from DAK is expected to encourage economic growth (Sularso and Restianto, 2011). Based on the explanation, the proposed hypothesis is as follows.

\section{H3: Capital Expenditure mediates DAK effect on economic growth}

\section{Capital Expenditure mediates Tax/Non Tax DBH effect on Economic Growth}

The revenue-sharing fund comes from taxes and natural resources. DBH is based on principle by origin with channeling based on revenue realization. Wandira (2013) explains that DBH is a potential source of local revenue and is one of the basic capital of local government in obtaining development funds and meeting regional expenditures other than those derived from PAD, DAU and DAK. Taaha et al. (2009), found a positive relationship between DBH and economic growth. DBH allocation as a source of infrastructure financing in the form of economic facilities and infrastructure will support the production activities of goods and services by investors, either from the local community or from outside the area concerned. Activity of further investment activities will create job opportunities, and create multiple effects that encourage economic growth (Hendriwiyanto, 2014; Pujiati, 2008; Santosa, 2013).

Rostow and Musgrave (1996) explain that the pattern of government capital expenditure in the early stages of economic development is characterized by the large percentage of government investment to total investment. This is because the government must provide infrastructure and infrastructure for education, health and transportation. Therefore, the increase of DBH has an impact on the increase of capital expenditure. Thus, the proposed hypothesis is as follows.

H4: Capital Expenditure mediates Tax/Non Tax DBH effect on Economic Growth

\section{RESEARCH METHODS}

This type of research is explanatory with archival data survey design. Dependent variable in this research is economic growth at regencies / city government in Bengkulu Province which is real increase of physical goods and service production capacity in a certain period with quantitative measure using 
GRDP at constant 2010 prices in percent unit. Mediation variable at this research is capital expenditure that is realization of capital expenditure at district / city government in Bengkulu Province. Capital expenditures represent budgetary expenditures for the acquisition of property and equipment and other assets (fixed assets) that benefit more than one accounting period, consisting of land expenditures, equipment and machinery expenditures, building and building expenditures, road Expenditure, irrigation and asset networks and expenditures others, measured in millions of rupiah.

The independent variables in this study are PAD, DAU, DAK and DBH. Local revenue (PAD) in this research is PAD at district / municipality government in Bengkulu Province, which is all regional revenue derived from indigenous economic source determined by local regulation. Indigenous revenues are separated into four types of revenues: local taxes, regional retributions, the results of management of separated property, and other legitimate PAD measured in millions of rupiah. DAU in this study is the realization of DAU from the amount of transfer receipts granted by the central government to district / municipal governments in Bengkulu Province derived from APBN revenues and allocated for the purpose of equitable inter-regional financial capacity to fund regional needs in the context of decentralization implementation as measured in millions of rupiah. The DAK in this study is the realization of a special allocation fund (DAK) which is the amount of DAK received by the central government to the district / municipal governments in Bengkulu Province derived from APBN revenues and allocated for the purpose of assisting in financing specific activities which are regional and appropriate with national priorities measured in millions of rupiah. Tax / non-tax revenue sharing $(\mathrm{DBH})$ in this study is the realization of tax-sharing $\mathrm{DBH} /$ nontax revenues from the amount of transfer receipts granted by the central government to the district / city government in Bengkulu Province derived from APBN revenues and allocated to the regions based on percentage figures to finance regional needs in the context of decentralization in the form of regional portions derived from land and building taxes other than the land tax and rural and urban sector buildings, income tax article 25, income tax article 29 personal domestic taxpayers and income tax article 21. Meanwhile, natural resource-sharing funds are part of areas derived from natural resources, forestry, fishery, general mining, petroleum mining, natural gas mining and geothermal mining, measured in millions of rupiah.

Secondary data in the form of panel data (combined time series and cross section), sourced from Report of Audit Result (LHP) of BPK RI of Bengkulu Representative on Local Government Financial Report (LKPD) Book I in 10 (ten) regencies / cities in Bengkulu Province in the period 2009-2015. The data sources contain realization of PAD, DAU, DAK, DBH tax / non-tax revenue share, and capital expenditures that have been audited. Meanwhile, the secondary data of economic growth is obtained through the publication of Badan Pusat Statistik.

Data analysis method used in this research is Baron and Kenny mediated regression (1986). Before hypothesis testing is done, testing begins with the fulfillment of classical assumptions. The entire testing process uses the help of SPSS and Eviews software.

\section{ANALYSIS AND DISCUSSION}


Mediating Effect of Capital Expenditure on the Effect of Revenues, Allocation Fund, and Tax/Nontax Sharing on Economic Growth (Empirical Study of Regencies in Bengkulu Province

Period of 2009-2015)

In determining the regression estimation approach using panel data, it must first be tested through Chow test and Hausman test on three model approach ie pooled least square model, fixed effect model and random effect model. The summary of the model estimation and comparative model of equations in I to IV with Chow test and Hausman test, can be seen in Table 1 below.

Table 1 Summary of Model Comparison and Estimation

\begin{tabular}{|c|c|c|c|c|c|c|c|c|}
\hline & \multicolumn{2}{|c|}{$\begin{array}{l}\text { Equation I } \\
\text { Fixed Effect Model }\end{array}$} & \multicolumn{2}{|c|}{$\begin{array}{c}\text { Equation II } \\
\text { Random Effect Model }\end{array}$} & \multicolumn{2}{|c|}{$\begin{array}{l}\text { Equation III } \\
\text { Random Effect Model }\end{array}$} & \multicolumn{2}{|c|}{$\begin{array}{l}\text { Equation IV } \\
\text { Random Effect Model }\end{array}$} \\
\hline & Koef. & $\mathrm{T}$ & Koef. & $\mathrm{T}$ & Koef. & $\mathrm{T}$ & Koef. & $\mathrm{T}$ \\
\hline $\mathrm{C}$ & 4.468241 & 13.37093 & $3.27 \mathrm{E}+10$ & 1.905275 & 6.027388 & -1.642506 & 5.196503 & 18.11705 \\
\hline $\begin{array}{l}\mathrm{LN} \\
\text { PAD }\end{array}$ & $-4.40 \mathrm{E}-11$ & $-5.156616^{*}$ & 0.867656 & $2.214698 * *$ & - & - & $-9.95 \mathrm{E}-12$ & -1.352202 \\
\hline $\begin{array}{l}\mathrm{LN} \\
\text { DAU }\end{array}$ & 7.67E-12 & $5.384627^{*}$ & 0.068100 & 1.009897 & - & - & $6.00 \mathrm{E}-12$ & $5.080766 *$ \\
\hline $\begin{array}{l}\text { LN } \\
\text { DAK }\end{array}$ & $-1.03 \mathrm{E}-11$ & $-3.124892 *$ & 0.930782 & $6.087339 *$ & - & - & $-2.08 \mathrm{E}-12$ & -0.588062 \\
\hline $\begin{array}{l}\mathrm{LN} \\
\mathrm{DBH}\end{array}$ & $-1.97 \mathrm{E}-12$ & -0.279503 & -0.040981 & -0.128372 & - & - & $-5.97 \mathrm{E}-12$ & -1.187709 \\
\hline $\begin{array}{l}\mathrm{LN} \\
\mathrm{BM}\end{array}$ & - & - & - & - & $-3.04 \mathrm{E}-12$ & -1.642506 & $-9.87 \mathrm{E}-12$ & $-5.218915^{*}$ \\
\hline $\mathrm{F}$ & 5.984654 & & 29.73775 & & 2.698909 & & $13.57195^{*}$ & \\
\hline $\mathrm{R}^{2}$ & 0.581466 & & 0.646645 & & 0.038175 & & 0.514636 & \\
\hline $\begin{array}{l}\mathrm{Ad} \\
\mathrm{R}^{2}\end{array}$ & 0.484307 & & 0.624900 & & 0.024030 & & 0.476717 & \\
\hline
\end{tabular}

Sources: Data processed, 2016.

The first hypothesis (H1) examines the role of capital expenditure in mediating the effect of PAD on economic growth. The results showed that capital expenditure did not mediate the effect of realization of PAD on economic growth in regencies / cities in Bengkulu Province. Thus, Hypothesis one (H1) is rejected. This indicates that capital expenditure has not played a role in mediating PAD to economic growth in regencies / cities in Bengkulu Province in the period 20092015. The increase in capital expenditures sourced from PAD with the value of 0.867656 elasticity is not able to influence the increase of economic growth but it actually plays a role in realizing the economic slowdown. This is a contradictory condition of the objectives of APBD management, namely the realization of people's welfare through the improvement of economic growth.

Based on the results of the research shows that the realization of PAD with an average value of Rp. 23,044,366,792.46 has been allocated optimally to capital expenditure, but capital expenditure derived from PAD is in fact precisely the role of realizing the economic slowdown. This indicates that the allocated capital expenditures are unproductive capital expenditures that do not directly impact the driving force of economic activity. As known, based on Permendagri Number 21 Year 2011, capital expenditure is generally divided into 2 (two) major groups, namely capital expenditures for apparatus in the provision of government infrastructure and capital expenditure for provision of public service infrastructure infrastructure facilities. The type of capital expenditure allocated by districts / 
municipalities in Bengkulu Province for the period of 2009-2015 is dominated by the types of capital expenditures that meet the needs of apparatus such as the construction of office buildings, the purchase of official apparatus vehicles, the procurement of office furniture, purchases, the construction of office / computer office equipment, projector tools, cameras, handycam, monument construction, monument construction, and purchase of office land. Furthermore, added capital expenditures for the fulfillment of the needs of this apparatus tend to be spent outside the region, such as buying a service vehicle, so that economic activity does not occur within the region. The more budget allocated to this type of capital expenditure to meet the needs of this apparatus, it will further reduce the share of productive capital expenditures that touch the economic activities of the community at the APBD. It is also supported by the allocation of capital expenditures for infrastructure development which is not effective in providing benefits and the impact of economic growth improvement, such as the construction of an untapped regional government mess, a monument that can become a tourist attraction not well managed so as to become abandoned assets, and traditional markets has been built but not utilized for the activity of buying and selling society so that become market building which become gathering of livestock because not correct in setting location of market development likewise with terminal. If wellearned allocated capital expenditures are increasingly distorted, this will certainly have an impact on the economic slowdown.

Indeed, capital expenditure is allocated to productive capital expenditure that touches the economic activities of the community such as capital expenditures for road construction, bridges, construction of market buildings, irrigation development, procurement of water transportation equipment, air transport equipment, land transportation equipment, livestock procurement, procurement of seeds, agricultural equipment, telecommunication procurement, land purchase for the market, terminal construction, construction of slaughterhouses, dock construction, airfield construction, procurement of agricultural land, procurement of plantation land, livestock procurement, public recreation facilities and others appropriately, construction time or place or location. The availability of infrastructure and infrastructures will be the attraction of incoming investment, the production of goods and community services will increase, the efficiency of economic activity, economical, suppress inflation and the increase of money circulation. So the impact of this capital expenditure will affect the growth of economic growth. This figure shows that despite an increase in income, but when shopping management is done inappropriately, the outcomes generated will deviate far from the goal.

The results of this study are slightly different from the Directorate General of Regional Finance Ministry of Home Affairs (2013) that PAD has not been able to encourage the allocation of capital expenditures, because in general the local government is still dependent on regional transfers. This means that the PAD is not significant to the capital expenditure because the portion of PAD is still relatively small, not because it is not appropriate in determining the type of realized capital expenditure. While the results of this study show that, although the realization of PAD is still relatively small (3.8 percent) of revenues in APBD), PAD has been able to affect capital expenditure, but the allocation on the type of capital expenditure is still not appropriate because it is still dominated by unproductive capital expenditure. 
Mediating Effect of Capital Expenditure on the Effect of Revenues, Allocation Fund, and Tax/Nontax Sharing on Economic Growth (Empirical Study of Regencies in Bengkulu Province

Empirical facts of this study then support Agency Theory (Jensen and Meckling, 1976) and Einsenhardt (1989), which states that between the principal as the owner of capital and agent as the recipient of the delegation of authority often occurs agency conflict. This is because principal and agent have different goals and desires. People as the principal mandate the government as an agent to organize the government with the goal of improving the welfare of society. But in the process of such mandate occurs asymmetric desire, especially on public sector budgeting. The tendency of agents to be opportunistic in allocating and realizing the budget is not in accordance with the wishes and goals of the owners of capital. Related to the results of this research, the agent in realizing PAD is not allocated for productive capital expenditure that directly touches the economic activities of the community, but tends to allocate to capital expenditure to meet the needs of the apparatus, thus reducing the share of capital expenditure for the community. This has an impact on the economic slowdown.

The second hypothesis $(\mathrm{H} 2)$ examines the role of capital expenditure in mediating the effect of DAU on economic growth. The results show that capital expenditure does not mediate the influence of DAU on economic growth in Bengkulu Province. Thus, Hypothesis two (H2) is rejected.

Based on the estimation result of equation I, explaining that the increase of DAU realization will lead to an increase of economic growth in regencies / cities in Bengkulu Province. Similarly, if the opposite happens, if the allocation and realization of DAU decreases or is trimmed, it will significantly lead to an economic slowdown. DAU is a balancing fund transferred to the regions in order to reduce the inequality of financial capabilities between regions in Indonesia. In the districts of Bengkulu Province, DAU is the main source of revenue in APBD posture, as is the case with the majority of regions in Indonesia. In the period of 2009-2015, the average realization of DAU to total regional revenues in districts / cities in Bengkulu Province amounted to 67.65 percent. So it can be said that the velocity of money in districts / cities in Bengkulu Province sourced from APBD, 67.65 percent was contributed by the realization of this fund. The velocity of money in the regencies / municipality in Bengkulu Province then causes an increase in economic growth. However, the reality of the results of this study shows the velocity of money sourced from the DAU is not optimally allocated to capital expenditure. Indeed, an increase in the realization of DAU with an average value of Rp. $363,220,898,935.21$ is directly proportional to the increase in capital expenditure which gives direct impact to economic growth, so that the growth of economic growth can be optimal.

The broad scope of the DAU allocated under the regulation, has resulted in local governments having an opportunity not to prioritize the allocation of DAU to capital expenditures. The optimum portion of capital expenditure realization sourced from DAU by district / municipal government in Bengkulu province is the cause of not yet significant role of capital expenditure in spurring economic growth. The allocation of revenues sourced from the DAU on APBD is still dominated by personnel expenditure.

As it is known that DAU is a transfer fund given by the central government to the regional government that is a block grant. That is, the use is submitted to the region in accordance with the priorities and needs of the regions for improving services to the community in the context of implementation of regional autonomy. 
The allocation of DAU regulated by regulation can be allocated to personnel expenditures, capital expenditures, goods and services expenditures, grant expenditures, unexpected expenditures, interest expenditures, subsidy Expenditure and revenue-sharing expenditures to village governments. In the APBD posture, personnel expenditure still dominates, thus causing capital expenditures to be distorted. That is, personnel expenditure is still a shopping sector that became the main focus of APBD. Whereas with the DAU as the largest contributor to APBD revenues, it gives an opportunity for the local government to allocate DAU to capital expenditure optimally. However, these opportunities are not utilized by local governments in order to maximize economic growth through the realization of productive capital expenditures such as the allocation of land, equipment and machinery, roads, irrigation, networks, buildings and buildings that touch the needs of economic activities of the community.

Meanwhile, according to the PAN-RB Ministry, by the end of 2015 there are 235 local governments that have personnel Expenditure above $50 \%$ of the total APBD. Furthermore, according to Director General of Fiscal Balance of the Ministry of Finance of the Republic of Indonesia (2016), the average portion of district / municipality expenditures on APBD in Indonesia in 2015 reached 46 percent. It is not much different from the districts / cities in Bengkulu Province that based on the Audit Report (LHP) of BPK RI on the Local Government Financial Report of the regencies / municipality in Bengkulu Province, in 2015 the average realization of personnel expenditure on APBD is 46,41 percent to income ( $\mathrm{Rp}$ $351,008,329,439.63)$, in the year 2014 the average realization of personnel expenditure of 54.24 percent $(\operatorname{Rp} 348.408 .298 .750,79)$ and in the year 2013 was 51.53 percent $(\operatorname{Rp} 314,206.142 .227,40)$.

The empirical facts indicate that the increase of regencies / city economic growth in Bengkulu Province has not been initiated by capital expenditures sourced from the realization of DAU. DAU-driven economic growth is attributed to government consumption Expenditure on employee Expenditure and Expenditure on goods and services, which is certainly not as optimal as if they were allocated to productive capital Expenditure.

Furthermore, based on the results of research can be explained that the allocation of capital expenditures in the APBD on districts / cities in the province of Bengkulu sourced from DAU has not reached the optimal portion to be able to spur economic growth, Based on LHP BPK RI, the realization of capital expenditures districts / cities in Bengkulu Province for the period 2009-2015 amounted to 23.11 percent of revenue. DAU has not contributed to the portion. The portion of capital expenditure should be able to reach at least 30 percent of APBD revenues (as directed by the Ministry of Home Affairs 2013 and finance ministry 2014) if the DAU contributes to realization of productive capital expenditure. The average realization of distrit/city capital expenditures in Bengkulu Province in the period 2009-2015 amounted to 23.11 percent is not able to encourage economic growth in the district / city in the province of Bengkulu well. The result of the research shows that the fact that illustrates in the non optimal portion (23.11 percent) has been burdened also by capital expenditure for the fulfillment of personnel requirement such as official vehicle expenditure, official housing expenditure, office building expenditure, machine and office equipment expenditure such as computer, handycam, genset, infocus and so forth. So that 
Mediating Effect of Capital Expenditure on the Effect of Revenues, Allocation Fund, and Tax/Nontax Sharing on Economic Growth (Empirical Study of Regencies in Bengkulu Province

productive capital expenditure for the provision of infrastructure and infrastructure for the community is again distorted by unproductive capital expenditures.

The results of this study support the concept proposed by Anthony and Govindarajan (1995) which states that one key element of agency theory is that principal and agent have different preferences and goals, all individuals acting on their behalf. Agent in this case the district / city government is not optimal in implementing the contract given by the people as principal in improving their welfare. So asymmetric interest continues, without any significant evaluation and follow-up in improving the structure and posture of the APBD focusing on productive Expenditure on improving economic growth.

The third hypothesis (H3) examines the role of capital expenditure in mediating the impact of DAK on economic growth. The results showed that capital expenditure did not mediate the effect of DAK realization on economic growth in regencies / cities in Bengkulu Province. Thus, Hypothesis three (H3) is rejected. These findings indicate that capital expenditure has not played a role in mediating the impact of DAK on economic growth. This is a conclusion from the results of research which states that the increase of DAK realization causes an economic slowdown, although the increase of DAK realization impacts to the increase of capital expenditure realization. But the realization of this capital expenditure in reality does not spur an increase in economic growth. Furthermore, when DAK together with capital expenditure tested its impact on economic growth, it turned out that DAK did not give a role to economic growth and the increase of capital expenditure realization would cause economic slowdown.

However, the significant realization of DAK in spurring capital expenditure was not able to boost economic growth, but instead led to an economic slowdown. This is because the type of capital expenditure allocated is still dominated by the type of capital expenditure that touches health and education infrastructure facilities, so the allocation of capital expenditure on productive type has a relatively small portion. The average realization of DAK in regencies / cities in Bengkulu Province is Rp51.454.749.078,57. When compared with the average income in the district / city APBD in Bengkulu Province, the DAK contribution is 9.85 percent.

The frequent delays in the handover of operational guidelines and technical guidelines from the central government to the local government and the late delivery of DAK implementation reports from local governments to the central government resulted in delays in the implementation of the absorption or realization of DAK. Furthermore, there is an obligation to provide DAK counterpart funds to the APBD at a minimum of 10 (ten) percent of the total DAK, so that the allocation and companion for the development of public health centers, schools and others will reduce the allocation of other productive expenditures. If DAK is realized larger, capital expenditures will be higher, this will be followed by a larger companion fund as well. In turn it will cause an economic slowdown. Because APBD revenues are absorbed into Expenditure that is not a stimulant to increase production of goods and services that increase people's incomes.

In general it can be explained that capital expenditures do not mediate the impact of DAK realization on economic growth due to the relatively small portion of DAK, allocation of capital expenditures on non-productive Expenditure, delays in the distribution of operational guidelines and technical guidelines and 
compensation funding obligations for DAK by 10 per cent APBD. This has an impact on the economic slowdown.

The government aims to allocate DAK to local governments to support the achievement of national priorities both through physical DAK and NonPhysical DAK. Physical DAK is mainly realized in the field of education and health. In addition, physical DAK is also allocated to the areas of sanitation and drinking water, settlement, irrigation, forestry transportation, marine, fishery and agriculture in general along with the facilities and infrastructure and so forth. Nonphysical DAK is allocated to the education sector (school operational assistance, PNSD teacher support allowance, operational assistance for early childhood education, etc.), health sector (health operational support and family planning operational assistance), and assistance for capacity building of cooperatives and SMEs.

DAK is allocated to priority areas such as underdeveloped areas, border areas, archipelagic coastal areas, disaster prone areas, areas of defense of food security, tourism developing areas. The regencies / municipalities in Bengkulu Province are regions that meet the criteria of the regions that receive DAK allocation priorities, namely underdeveloped regions, border areas, coastal areas of the archipelago, and disaster prone areas.

The increase of DAK realization in regencies / municipality in Bengkulu Province has a role to increase capital expenditure, this is because the allocation of DAK has been regulated by the central government through operational guidelines and technical guidelines. In accordance with the operational guidelines, the allocation of DAK is dominated by capital expenditures for the development of education and health infrastructure, such as the construction and rehabilitation of school buildings, health facilities in the form of development and rehabilitation of healthcare facilitation.

Furthermore, based on the results of research can be explained that the allocation of capital expenditures in the APBD on districts / cities in Bengkulu Province sourced from DAK has not reached the optimal portion to be able to spur economic growth, it happened something in the allocation so that the increase in capital expenditure led to economic slowdown. Based on LHP BPK RI, the realization of capital expenditure of regencies / cities in Bengkulu Province during the period of 2009-2015 is 23.11 percent of revenues, although the portion is not optimal yet approaching the minimum allocation of 30 percent (according to appeal of kemendagri 2013 and financial kemeneterian 2014). The average realized capital expenditure of 23.11 percent should be able to encourage economic growth in the regencies / cities in Bengkulu Province well. However, the result of the research shows that the fact that the portfolio is not optimal, the allocation of capital expenditures sourced from DAK is dominated by the development of educational infrastructure, the health that indirectly gives an impact to the increase of economic growth. So that productive capital expenditure for the provision of infrastructure and infrastructure for the community is again distorted by unproductive capital expenditures. The distribution of productive capital expenditures by unproductive capital expenditures is what causes the greater realization of capital expenditure in the regencies / cities in Bengkulu Province, hence it leads to an economic slowdown. This is because the greater the allocation of capital expenditures, the greater the companion funds should be allocated to DAK derived from APBD revenues, absorbed to capital expenditures for the fulfillment of educational 
Mediating Effect of Capital Expenditure on the Effect of Revenues, Allocation Fund, and Tax/Nontax Sharing on Economic Growth (Empirical Study of Regencies in Bengkulu Province

infrastructure facilities and the needs of the apparatus not for capital expenditure of infrastructure facilities and infrastructure.

The results of this study support the neo classical economic growth theory proposed by Solow-Swan, that factors that play a role in encouraging economic growth are labor, capital accumulation and technological progress. That is, the availability of capital in the form of good infrastructure is an important factor that must be met in order to build an increase in economic growth.

The fourth hypothesis (H4) examines the role of capital expenditure in mediating the effect of tax DBs / non-tax revenue share on economic growth. The results showed that capital expenditure did not mediate the effect of $\mathrm{DBH}$ realization on economic growth in regencies / cities in Bengkulu Province. Thus, Hypothesis four (H4) is rejected. These findings indicate that capital expenditure has not played a role in mediating DBH tax / non-tax revenue share on economic growth because the tax-sharing DBH / non-tax revenue share from central government to districts in Bengkulu Province has a relatively small portion of this, Rp.30.267.537.355,98 or $5.97 \%$ of total revenue in APBD. In addition, the relatively small portion of the tax-sharing / non-tax revenue DBH is partially allocated to capital expenditures. The results indicate that capital expenditures sourced from tax DBH / non-tax revenue share have been allocated to both types of capital expenditure that is productive and not productive. Allocation to unproductive capital Expenditure certainly does not provide an increase in economic growth. However, when tax-sharing / non-tax DBEs are allocated to productive capital expenditures it has an impact on the economic slowdown. This is because it is not right on the location of development, so that the economic infrastructure facilities become dormant and not functioning in spurring economic growth.

Furthermore, there is no mediating role of capital expenditure on the impact of tax-sharing DBH on tax / non-tax revenues on economic growth is also supported by the allocation of tax-sharing DBH / non-tax revenues to other expenditures, including personnel expenditures related to official travel, procurement of official clothing, honorarium pns, bansos Expenditure, grant expenditure, emergency response expenditures that do not directly impact economic growth. The dominance of regional travel expenditures impacts money circulating touched productive sectors outside districts / municipalities. Whereas according to Kuncoro (2014) the allocation of tax DBH / non-tax revenue share to overcome revenue from tax sources for the allocation of expenditure, based on a certain percentage adjusted to the potential producing regions. That is, one of the government's efforts to help the region to optimally allocate regional expenditure that aims to drive the local economy is through the tax-sharing DBH / profit sharing.

\section{CONCLUSION AND RESEARCH IMPLICATIONS}

This study aims to examine the effects of local revenue (PAD), general allocation funds (DAU), special allocation funds (DAK), tax-sharing / DBE funds on economic growth with capital expenditure as a mediating variable. The results did not find the effect of capital expenditure mediation. However, this study found the effect of PAD on economic growth and capital Expenditure, and the effect of DAU and DAK on economic growth and capital expenditure. The implications of the research results are as follows. 
a. Structural reforms in the priority areas of regencies budget APBD in Bengkulu Province need to be done.

b. In achieving the effectiveness of programs and activities that impact on the improvement of regional economic growth through capital expenditure, the capital Expenditure priority should really be realized to the type of capital expenditure that is productive, not the type of capital expenditure that actually re-meet the needs of employees such as official vehicles, office buildings which is not as needed.

c. An integrated and sustained monitoring, evaluation, and assessment should be carried out by the central government, the Inspectorate, BPKP and BPK RI on the allocation of productive capital expenditure in the management of expenditure.

d. Improving the management of government local business unit (BUMD) regarding to generate government revenues.

e. Program and activity priorities for infrastructure development sourced from DAK should be synchronized between top down and bottom up, thus creating a balance of program and needs priorities between central and local governments.

The central government needs to reconsider, the regulation governing the allocation ratio of tax-sharing $\mathrm{DBH} /$ non-tax revenue share to the areas that are responsible for preserving nature, such as maintaining the protected forest.

\section{References}

Andriana. (2009). Effect of PAD, DAU, capital expenditure on economic growth in Regencies of Central Java Province 2004-2007. Accessed from: http: //etd.repository.ugm.ac.id.index.php? $\bmod =$ opac \& sub $=$ Opac \& act $=$ view $\&$ typ $=$ html $\&$ perpus_id $=\&$ perpus $=1 \&$ searchstring $=$ Fund $\%$ 20allocation $\% 20 \&$ self $=1 \&$ op $=$ review

Anrianti, A. (2010). Effect of DAU, PAD and economic growth on capital expenditure. Accessed from: http: //etd.repository.ugm.ac.id.index.php? $\bmod =$ opac $\&$ sub $=$ Opac $\&$ act $=$ view $\&$ typ $=$ html \& perpus_id $=\&$ perpus $=1 \&$ searchstring $=$ Fund $\%$ 20allocation $\% 20 \&$ self $=1 \&$ op $=$ review

Anthony, R. N., \& Govindarajan, V. (1995). Management control systems. Illinois: Irwin Homewood.

Baron, R. M., \& Kenny, D. A. (1986). The Moderator-mediator variable distinction in Social Psychological Research: Conceptual, strategic, and statistical Consideration. Journal of Personality and Social Psychology, 51(6), 11731182.

Brata, A. G. (2004). Composition of public sector receipts and regional economic growth. Yogyakarta: The Research Institute of Universitias Atmajaya.

Directorate General of Regional Financial Management. (2013). Capital expenditure local government must reach 30 Percent. Jakarta: Ministry of Home Affairs. 
Mediating Effect of Capital Expenditure on the Effect of Revenues, Allocation Fund, and Tax/Nontax Sharing on Economic Growth (Empirical Study of Regencies in Bengkulu Province

Eisenhardt, K. (1989). Agency theory: An assessment and review. Academy of Management Review, 14, 57-74.

Gunantara, P. C., \& Dwirandra, A. A. N. B. (2014). Effect of PAD and DAU on economic growth with capital spending as moderate variables in Bali. $E$ Journal of Accounting for Udayana University, 3.

Hendriwiyanto, G. (2014). The Effect of regional income on economic growth with capital expenditure as moderation variables. Accessed from: download. portalgaruda.org> article.

Jensen, M. C., \& Meckling. W. H. (1976). Theory of the firm: Managerial behavior, agency cost and ownership structure. Journal of Financial Economics, 3, 305-360. North-Holland Publish Companey.

Kuncoro, M. (2014). Regional autonomy: Toward a new era of regional development. Issue 3 Jakarta: Erland.

Kurni, A. (2012). Effect of DAU and DAK on GDP of twenty regencies in Papua Province Period 2006-2010. Accessed from: http: //etd.repository.ugm.ac.id.index.php? $\bmod =$ opac $\&$ sub $=$ Opac $\&$ act $=$ view $\&$ typ $=$ html $\&$ perpus_id $=\&$ perpus $=1 \&$ searchstring $=$ Fund $\%$ 20allocation $\% 20 \&$ self $=1 \&$ op $=$ review

Kusnandar., \& Siswantoro, D. (2012). Influence of general allocation fund, local original income, remaining more budget financing and area to capital expenditure. Accessed from: http://pdeb.fe.ui.ac.id/?p=6616

Kuspita, M. (2015). Effect of PAD, DAU, DAK and SiLPA on capital expenditures realization and fffect of capital expenditures realization, private investment and labor against economic growth: Empirical study of regencies in Central Java Province. Accessed from: http: //etd.repository.ugm.ac.id.index.php? Mod $=$ opac \& sub $=$ Opac $\&$ act $=$ view $\&$ typ $=$ html $\&$ perpus_id $=\&$ perpus $=1 \&$ searchstring $=$ Fund $\%$ 20allocation $\% 20 \&$ self $=1 \&$ op $=$ review

Mardiasmo. (2009). Public sector accounting. Yogyakarta: Andi.

Novianto, R., \& Hanafiah, R. (2015). Effect of original income, balancing fund and financial performance of capital expenditure allocation at regencies in West Kalimantan Province. Journal of Economics, 4(1). ISSN: 2302-7169.

Oktrinniatmaja, R. (2011). The Effect of local income, general allocation funds and special allocation funds to allocation of capital expenditure budget in regional revenue and expenditure Budget of regencies In Java Island, Bali, and NusaTenggara. Retrieved from: http://eprints.uns.ac.id/5945/

Regulation of the Minister of Home Affairs Guideline for the Preparation of Regional Income and Expenditure Budget for Fiscal Year 2016, Number 52, (2015). 
Pujiati, A. (2006). Analysis of economic growth in Karasidenan Semarang fiscal desetralization era. Journal of Development Economics. Economic Study of Developing Countries, 61-70.

Rostow., \& Musgrave. (1996). Economic development planning. Jakarta: Raja Grafindo Pustaka.

Santosa, B. (2013). Effect of local income and regional development fund of growth, unemployment and poverty in 33 Provinces of Indonesia. Journal of Finance and Business. Universitas Trisakti Jakarta.

Solikin, I (2007). Relationship of revenue and general allocation funds with capital expenditure in West Java. Exclusive Journal , 4(4). Jakarta: Universitas Pendidikan Indonesia.

Sularso, H., \& Restianto, Y.E. (2011). Influence of financial performance on capital expenditure allocation and economic growth of regencies in Central Java. Media Research Accounting, 1(2).

Sumartini, N. K. A. (2015). Effect of PAD and DAU on economic growth through capital expenditure in Bali Province. E-Journal EP Unud, 4 (4), 258-271. ISSN: 2303-0178.

Taaha, Y. R., Nursini., \& Salim, A. (2009). Effect of balancing funds on economic growth in Central Sulawesi Province. Accessed from: http://pasca.unhas.ac.id $>$ journals $>$ files

Wandira, C. A. (2013). Effect of PAD, DAU, DAK and DBH on allocation of capital expenditures. Accounting Analysis Journal. Semarang State University. 